\title{
دراسة تحليلة عن لفظ سورة العصر ومعناها من ناحية علم النحو والبلاغة
}

\section{Muhammad Nurpahmi Himayaturrahman}

MTs Terpadu Adzkiya Mansyaul Hikam email: abisalman202@gmail.com

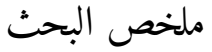

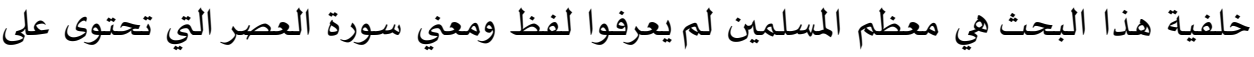

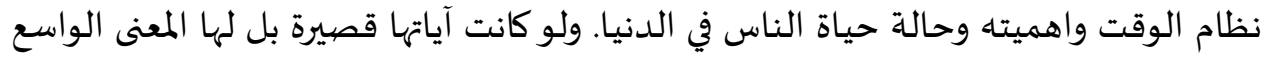

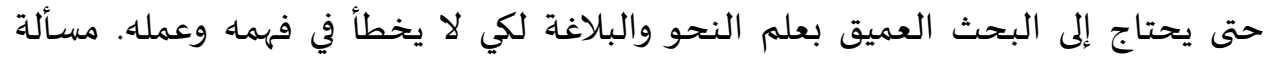

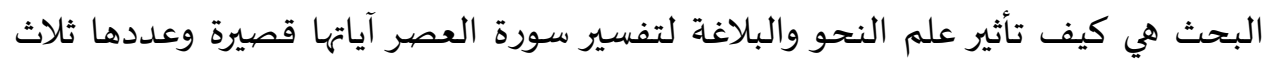

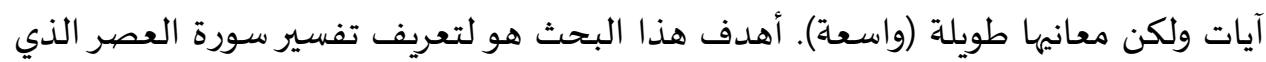

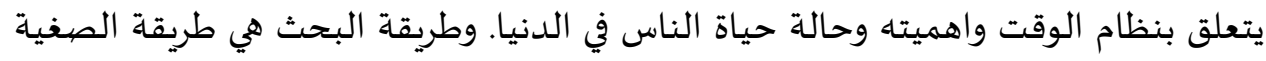

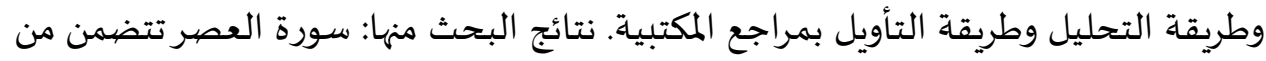

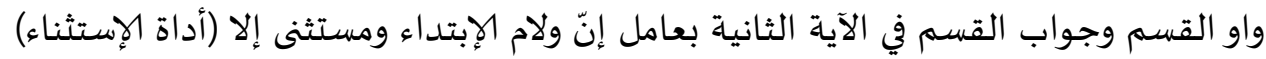

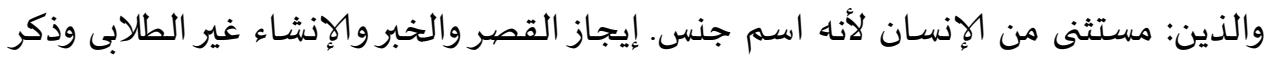

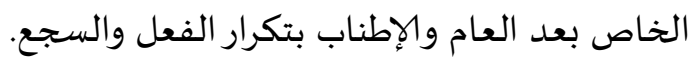
الكلمات الرئيسية: اللفظ, المعنى, سورة العصر, النحو البلاغة.

\footnotetext{
ABSTRAK

Penelitian ini dilatarbelakangi oleh kurangnya pengetahuan kaum muslimin terhadap makna ayat surat Al-'Ashr, urgensi dan management waktu. Masalah penelitian adalah bagaimana pengaruh ilmu nahwu dan balaghah terhadap penafsiran lafaz dan makna surat Al-'Ashr. Tujuan penelitian adalah mengetahui kandungan tafsir ayat surat Al-'Ashr yang berkaitan dengan urgensi dan manajemen waktu kehidupan manusia. Metode yang digunakan adalah metode analisis-deskriptif dan hermeunetik-interpretataif. Hasil penelitian ini adalah surat Al-'Ashr terdiri dari wāwu qasam dan jawäb qasam pada ayat kedua dengan 'ämil inna, lām ibtidā dan mustatśnā illā, fungsi dari wāwu qasam adalah untuk memperkuat kabar sehingga tidak diingkari, lafaz الذين mustatśnā dari lafaz karena lafaz tersebut adalah isim jinis. Surat Al-'Ashr juga terdiri dari ijäzul qașar, khabar, insyä ghair at-thalaby, dzikrul khās ba'da al-'àm, ithnäb dan saja'.

Kata Kunci: Lafaz, Makna, Surat Al-'Ashr, Nahw, Baläghah
} 


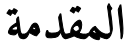

القرآن هو كلام الله الذي انزل على النبي محمد صلى الله عليه وسلم وليس مخلوقا.

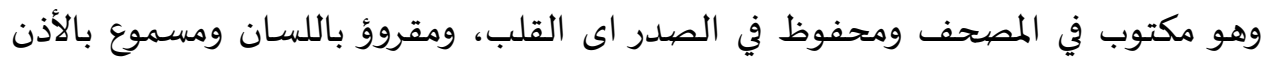

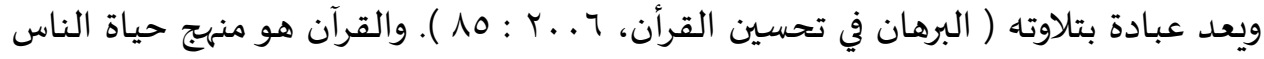

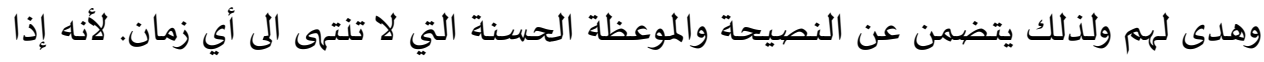
كان الإنسان يريد ان يعرف كل ما ذكر في القرآن وكشف جميع ولميع معانيه مستحيلا.

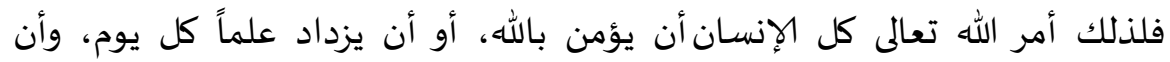

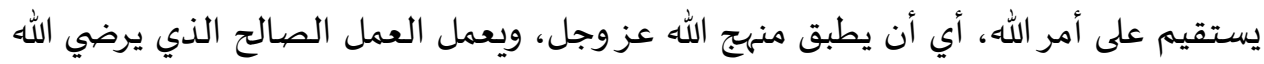

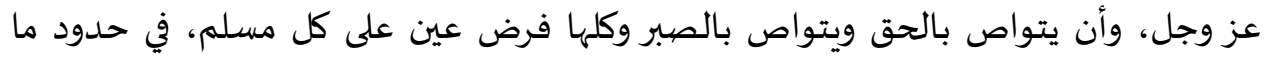
يعلم لمن يعرف، وأن يصبر على الطاعة، وعن المعصية، وعلى قضاء الله وقدره.

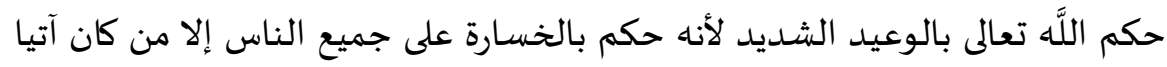

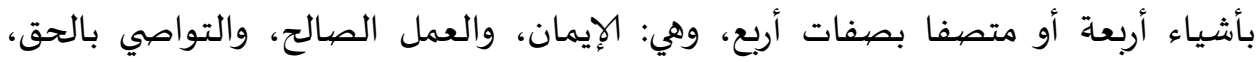

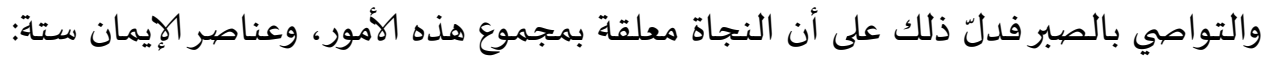

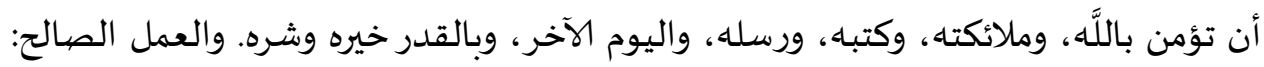

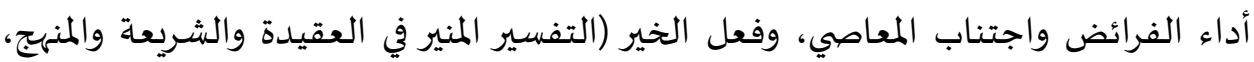
ص : (190: (190)

ليست النجاة بين يدي الله عز وجل بالمال أو الجاه، أو العلم، أو الابتكار، أو العمل الدنيوي المحض، أو غير ذلك من زخاف الحياة، ومظاهر العيش التي يتنافس فيها الناس،

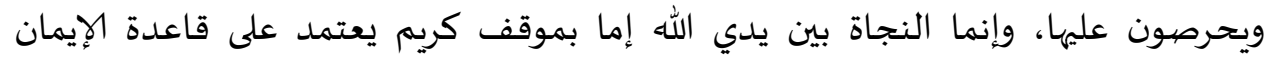
الصحيح بالله ورسوله.

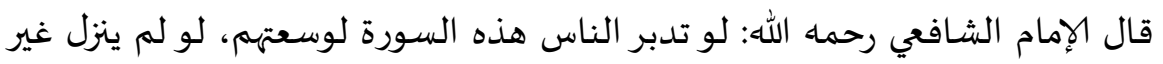

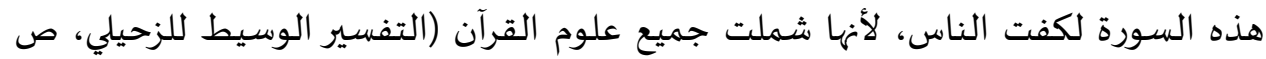

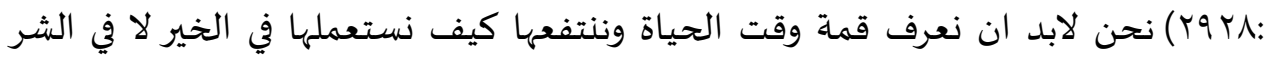

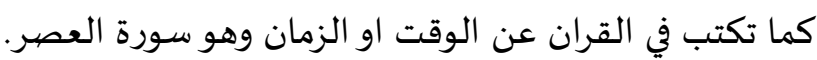

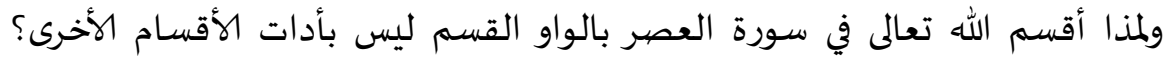

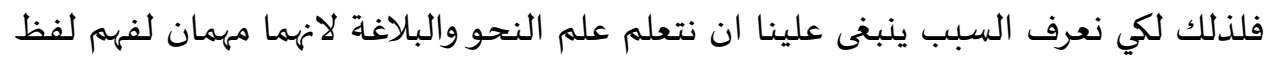
ومعنى آية القرآن ولاسيما تفسير سورة العصر الذي يتعلق بقسم الله عن الزمان. في سورة 
Ta’lim al-'Arabiyyah

العصر الآية الثانية كان لفظ الإنسان وله المرادف في اللغة العربية وهو لفظ البشر والناس وبنى آدم، وما الحكمة الله سبحانه وتعالى أن يستعمل هذا لفظ الإنسان في سورة العصر المريك ليس بغيره.

وقبل أن يجيب هذا السؤال ينبغي علينا أن نعرف كل حد منها كما يلي:

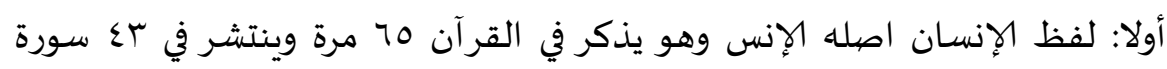

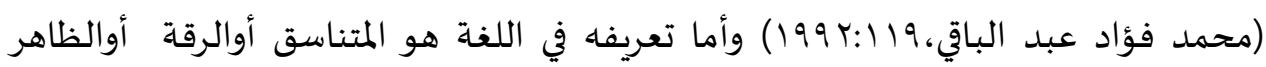
أوسريعة النسيان، فلفظ الإنسان يستعمل في القرآن لدلالاة على الإنسان بجميع عناصره

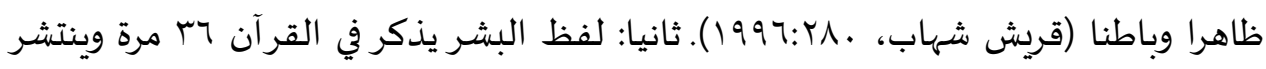

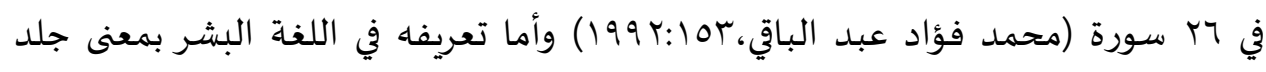
الرئس أوالوجه أو البدن الذي ينبت فيه الشعر. وهذا الإسم يدل على أنه بمعنى بيولوجيا

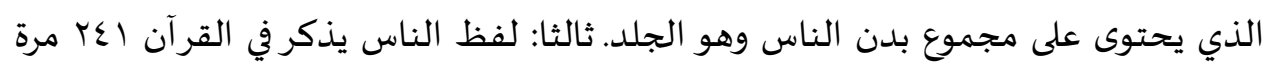

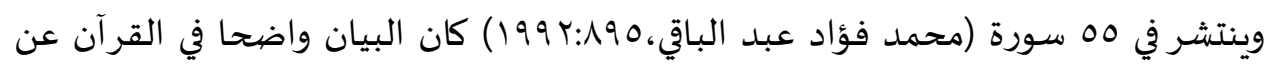
الناس الذي يدل على أنه درية نبينا آدام عليه السلام والناس يقال يسمى بالمخلوق الإجتماعى

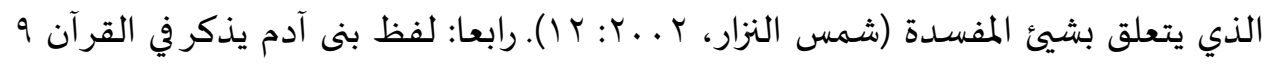

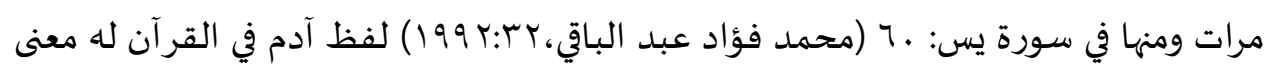

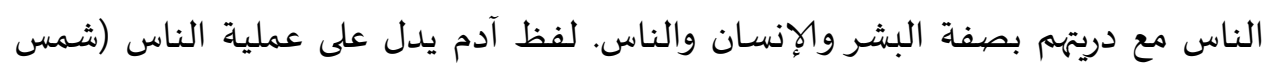

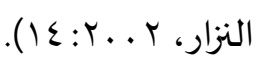
من ذلك البيان يرى الباحث أن حكمة الله تعالى يستعمل لفظ الإنسان الذي كان في

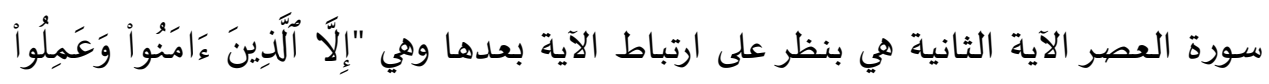

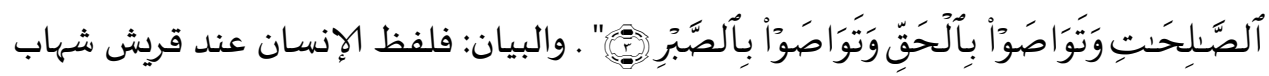
كما في بيان السـابق يستعمل في القرآن لدلالاة على الإنسان بجميع عناصره ظاهرا وباطنا،

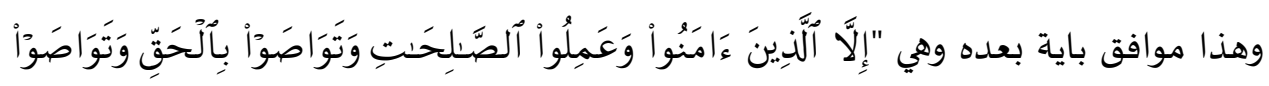
بألصَّبرِ

والمقصود: أن الإنسان الذي امن بالله تعالى وعمل عملا صالحا وتواصيو بالحق وتواصيو بالصبر هو يستثنى من الخسران يعنى أن الله سبحانه وتعالى يخبر على أن سعادة الإنسان في وعان 
أربعة الأشياء: الذين امنوا، وعملوا الصالحات، وتواصوا بالحق، وتواصوا بالصبر. المقصود

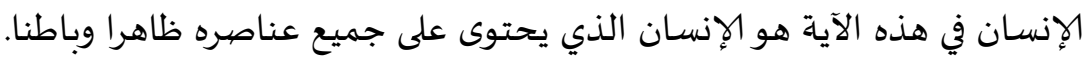

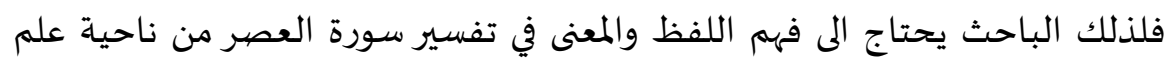
النحو والبلاغة. بناء على ذلك سيبحث الباحث البحث تحت العنوان "دراسة تحليلة عن لفظ ومعنى سورة العصر من ناحية علم النحو والبلاغة".

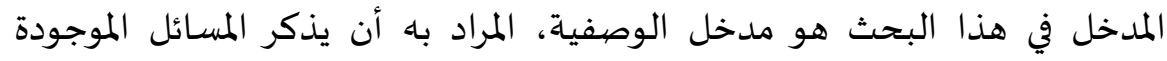

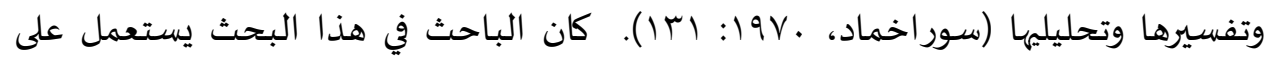

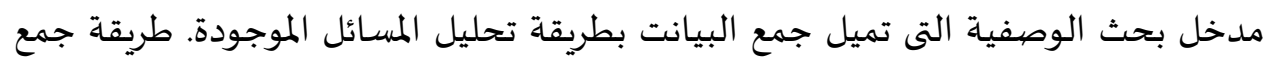
البيانات هو عملية منهجية قياسية لاكتساب البيانات المطلوبة وهذا يعنى أن الإرتباط بين

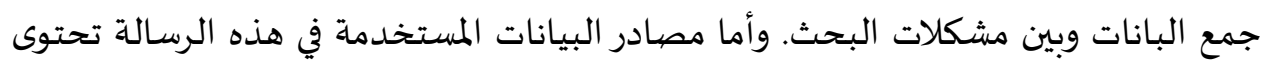
على البيانات الأولى و البيانات الثانية. البيانات الأولى هي القرآن عن سورة العصير. وأما

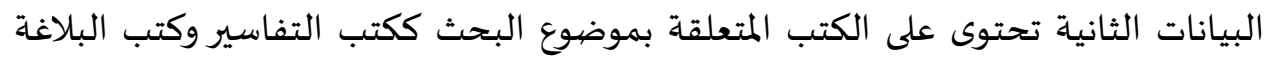

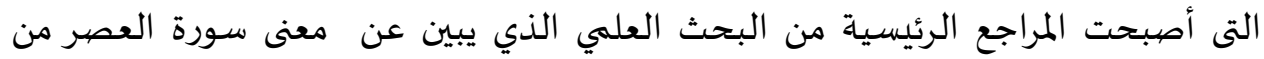

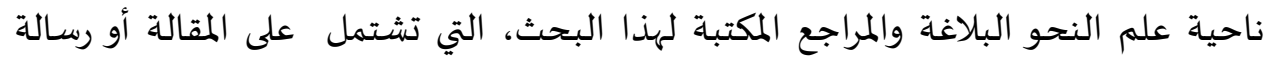
العلمية المتعلقة بهذا الموضوع.

يستخدم الباحث عن درس البحث بالمناهج التى تهدف مساعدة الباحث في جمع

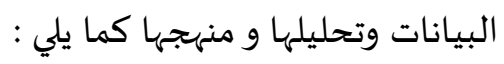

1. طريقة الصغية وطريقة التحليل (deskriptif-analisis) هي الطريقة التى تهدف على

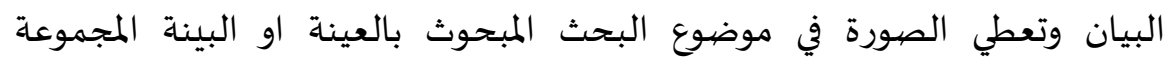

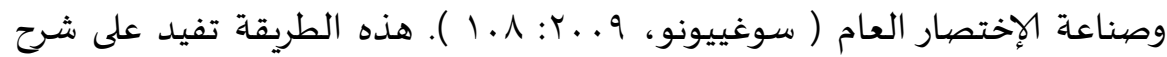

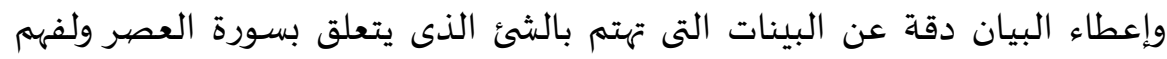

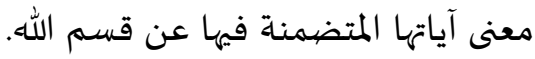
r. طريقة التأويل والتفسير (hermeunetik-intrepetatif) هي الطريقة لتفسير رموز بصورة النص او ما اشبه ذلك لبحث معانيه ( سودرتو، 1997: 17 ) ـ والهدف لتعبير

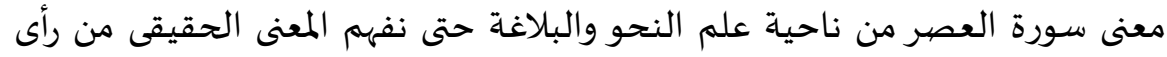
العلماء في تفسيره. 
Ta'lim al-'Arabiyyah

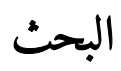

تعريف اللفظ

اللفظ وهي الرمي من الفم: لفظت الشيء من فهي الفظه لفظاً، رميته ثم يعدّد

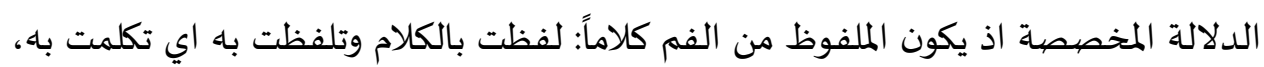

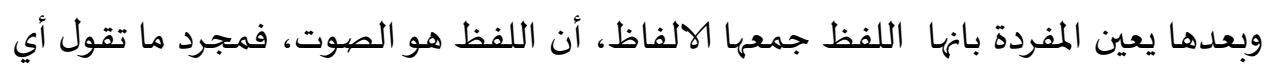

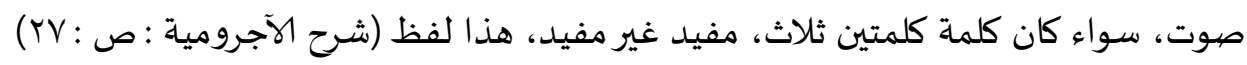

$$
\text { تعريف المعنى }
$$

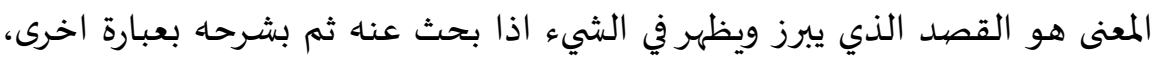

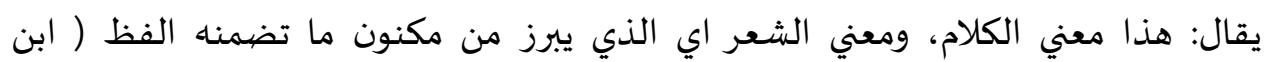

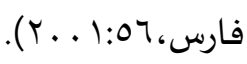

\section{سورة العصر}

سورة العصر هي مكيّة، وهي ثمانية وستون حرفا، وأربع عشرة كلمة، وثلاث آيات.

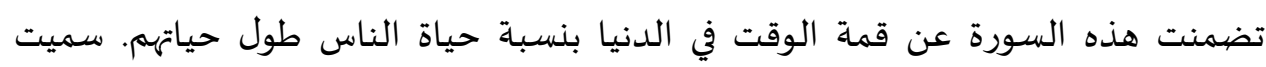

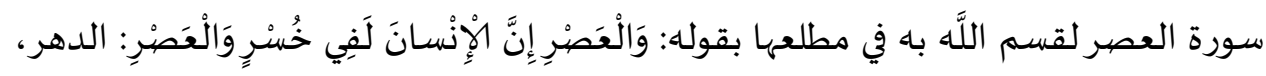

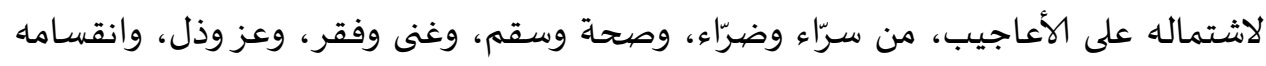

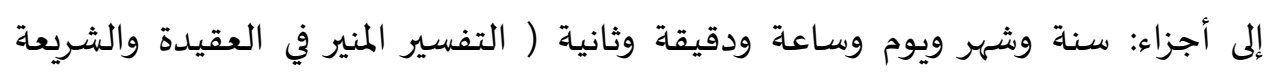

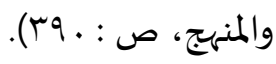

هذه السورة المكية الموجزة توضح أصهول الإسلام الكبرى، ودستور الحياة الإنسانية.

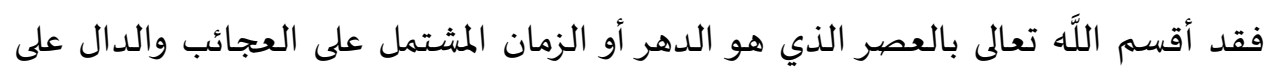

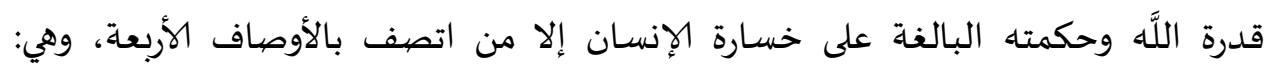

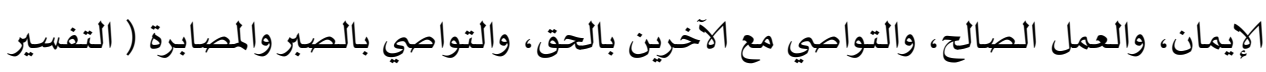
المنير في العقيدة والشريعة والمنهج، ص : (19).

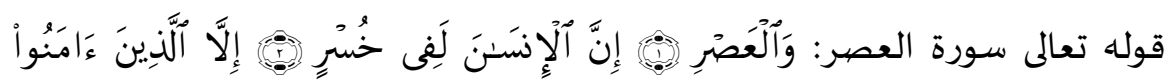

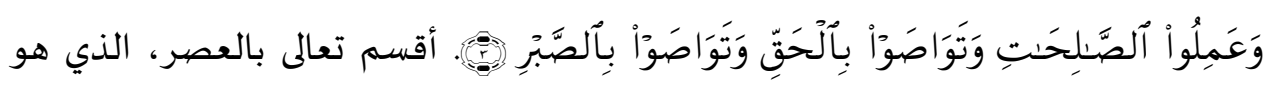

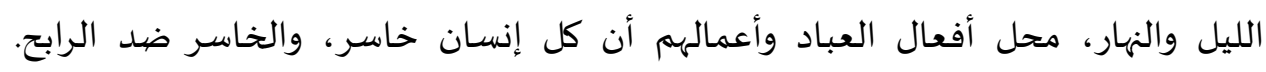


والخسار مراتب متعددة متفاوتة: قد يكون خسارًا مطلقًا، كحال من خسر الدنيا والآخرة،

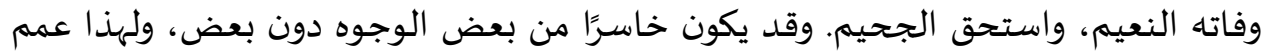

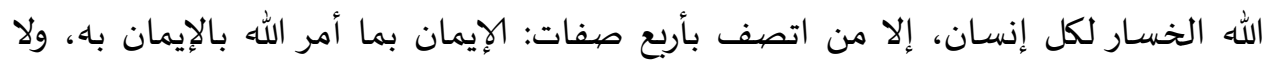

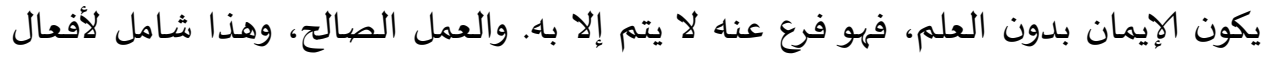

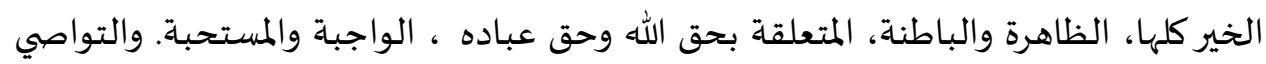

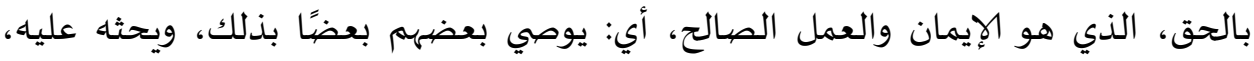
ويرغبه فيه. والتواصي بالصبر على طاعة الله، وعن معصية الله، وعلى أقدان الهار الله المؤلمة.

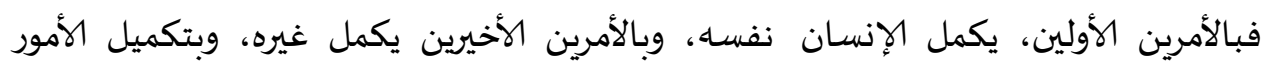
الأربعة، يكون الإنسان قد سلم من الخسار، وفاز بالربح [العظيم].

علم النحو

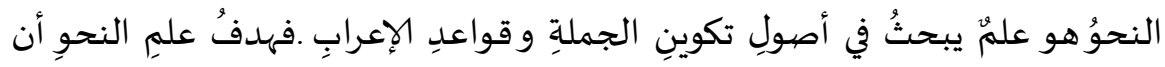

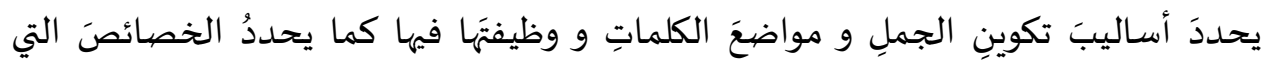

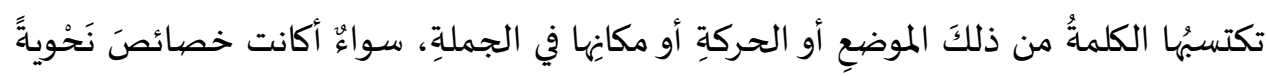

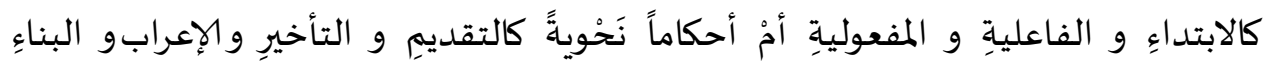
(دراسات في النحو: ص : 9).

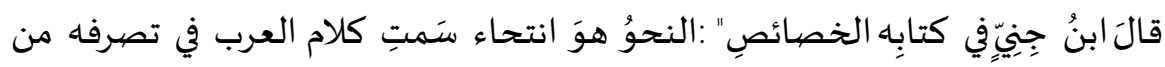

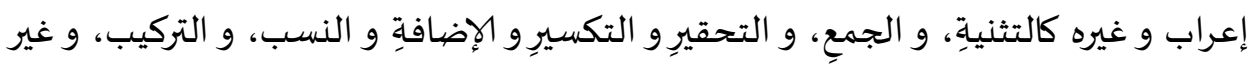

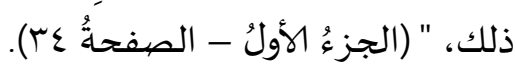

ينقسم حرف الواو إلى قسمين الواو العاملة والواو غير العاملة. وتنقسم الواواو الواو العاملة

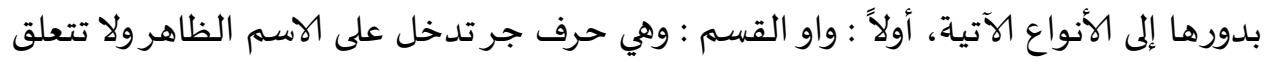

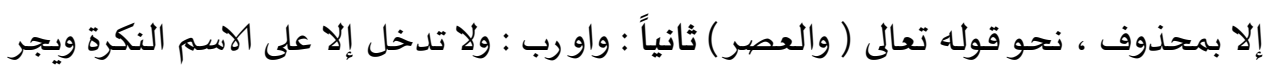

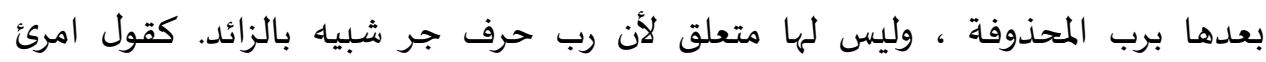

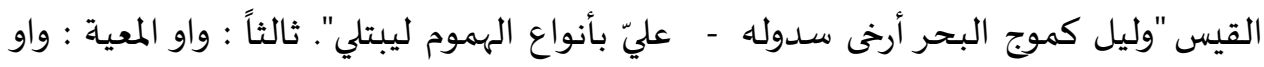

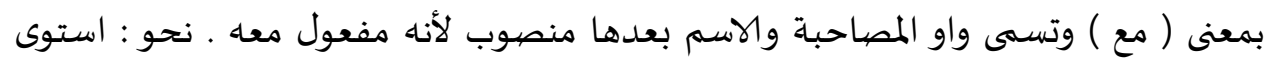

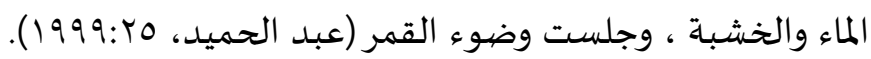

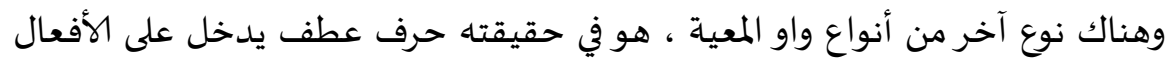

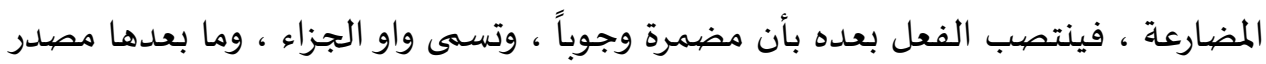


Ta'lim al-'Arabiyyah

مؤول معطوف على مصددر مؤول مقدر ، وشرطها أن يتقدم على الفعل طلب أو نهي كقول

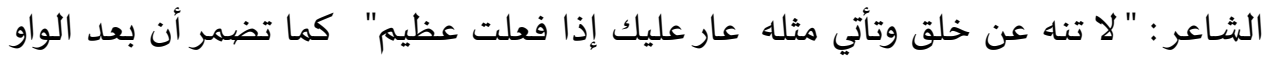

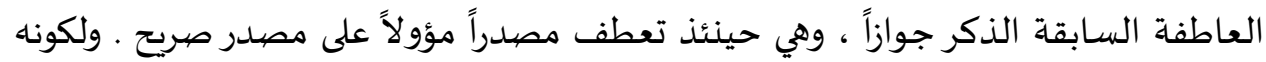

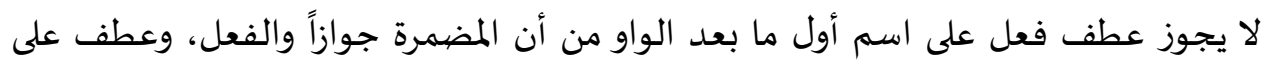

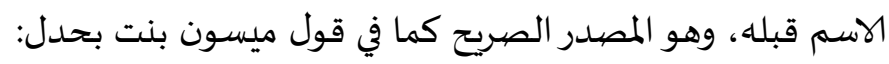

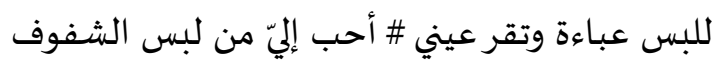

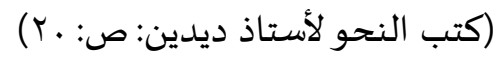

الواو غير العاملة وتنقسم إلى الأنواع الآتية، أولاً : واو العطف : حرف يجمع المتعاطفين

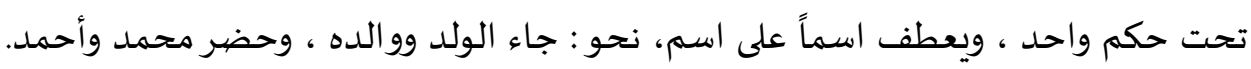

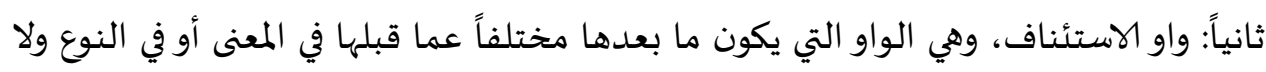

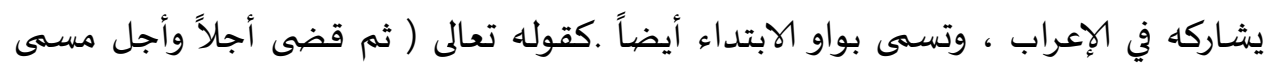

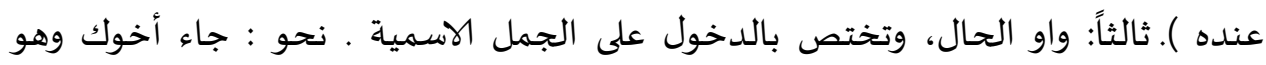

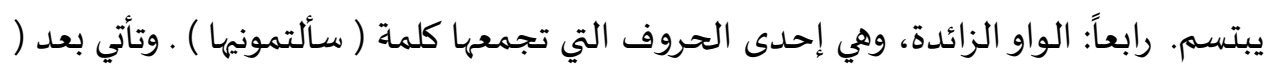
إلا ) للتأكيد كقوله تعالى ( وما أهلكنا من قرية إلا ولها كتاب الورات معلوم ).

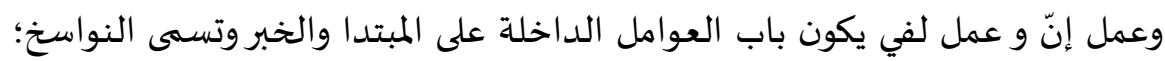

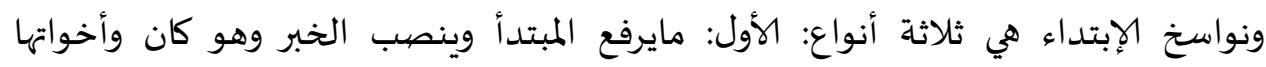

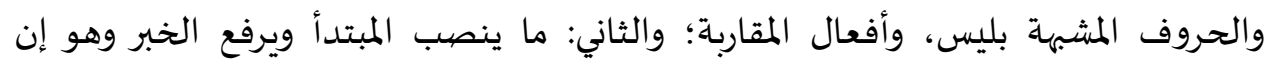
وأخواتها ولا التي تنفي الجنس؛ والثالث ما ينصب المبه المبتدأ والخبر جميعاً وهو ظن وأخوات واتها.

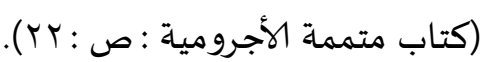

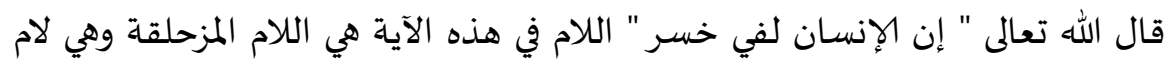

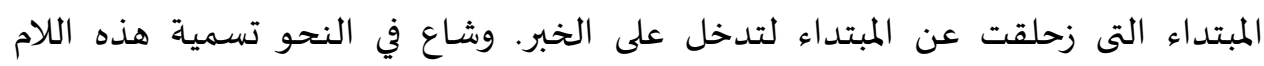

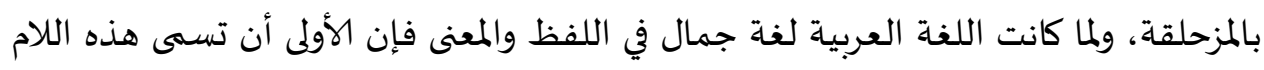

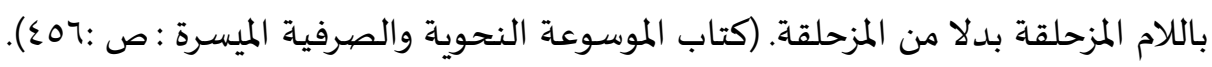

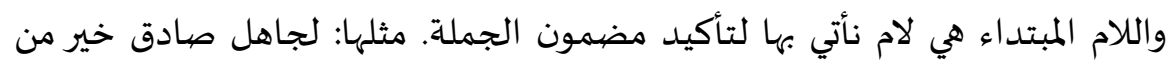

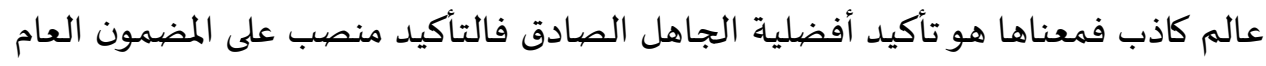

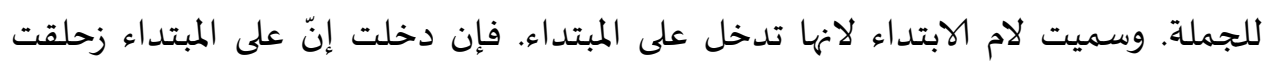

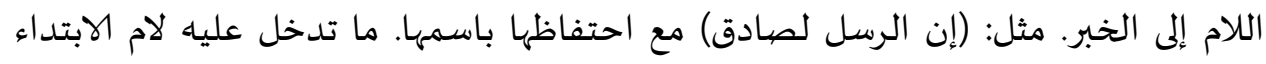

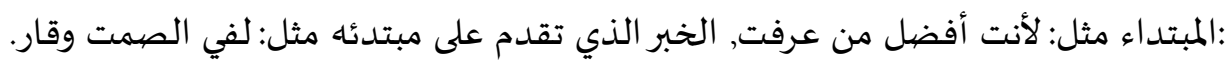




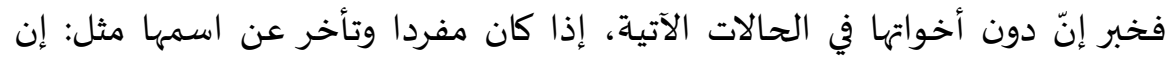
القاضي لعادل, إذا كان جملة اسمية مثل: إن الحق لسلطانه قوي, إذا كان جملة فعلية فعلها

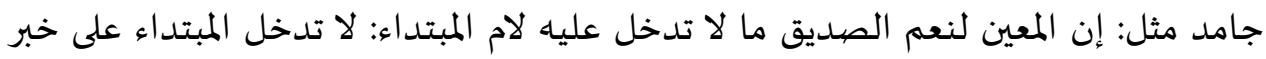

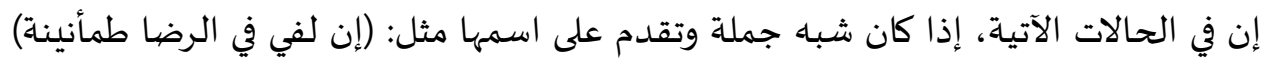
فلا تقل إن في الرضا طمأنينة.

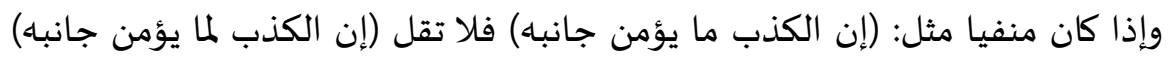
إذا كان جملة فعلية فعلها ماض متصرف غير مقترن بقد مثل: (إن الله كرم بنى آدم) فلا تقل

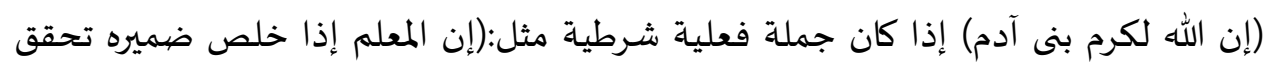
نفعه) فلا تقل (إن المعلم لإذا خلص ضميميره تحقق نفعانه).

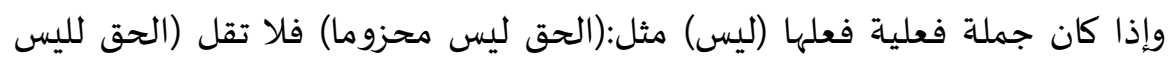

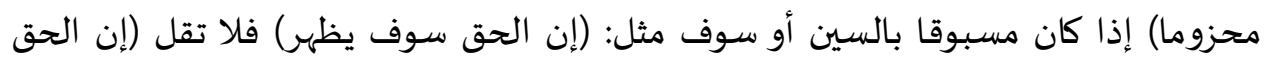

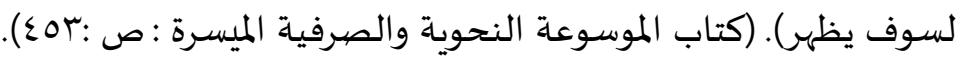

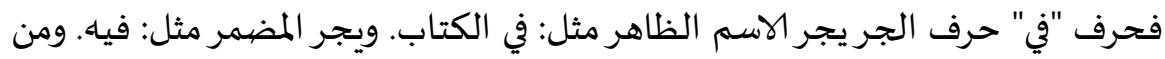

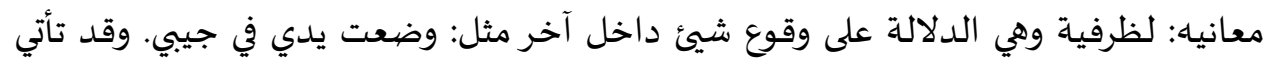

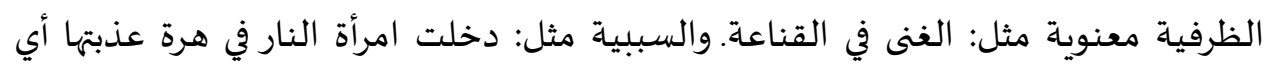

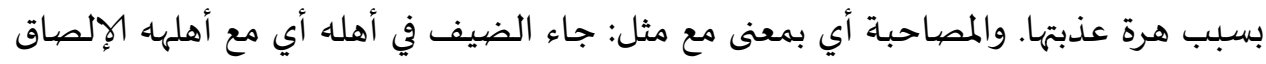
أي بمعنى الباء مثل: وقف السائل في الباب.

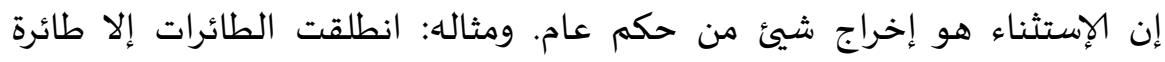

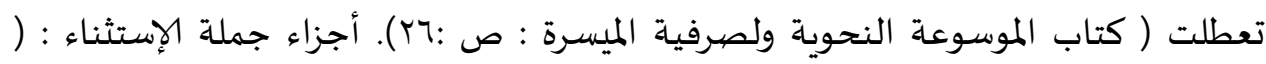
المستثنى منه + أداة الإستثناء + المستثنى) فالمستثنى منه في المثال السابق هو (الطائرات) و واد أداة

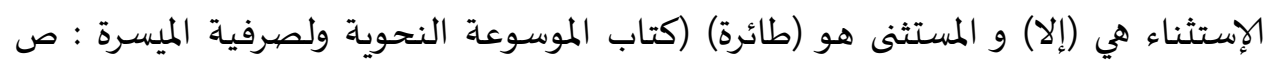
( ( r T:

فالاستثناء التام الموجب وهو مكون من : ( الفعل + المستثنى منه + أداة الإستثناء +

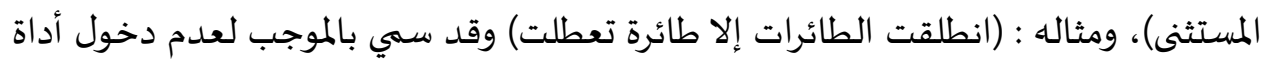

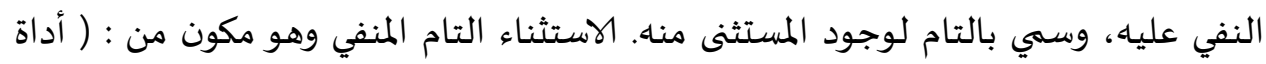

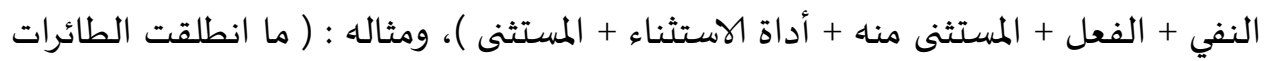

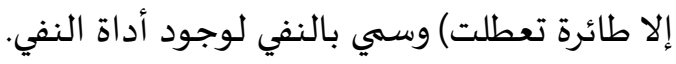


Ta’lim al-'Arabiyyah

والاستثناء المفرغ أو الاستثناء الناقص المنفي وهو مكون من : ( أداة النفي + الفعل + المستثنى )، ومثاله : ( ما انطلق إلا طائرة ) وسمي بالمفرغ أو الناقص لعدم وجواء مدود المستثنى منهـ.

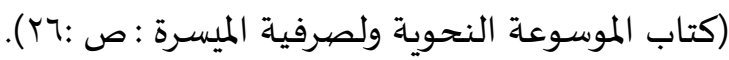

والاستثناء ينقسم الى قسمين الاستثناء المتصل وهو ماكان فيا المستثني من جنس المستثني مناه، ومثاله : انطلقت الطائرات إلا طائرة. والاستثناء المنقطع وهو ماكان فياه المستثني من جنس غير جنس المستثني منها، ومثاله: حضر الضيوف إلا حقائهه. (كتاب

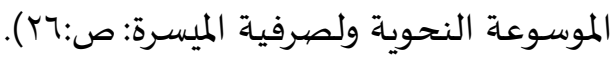

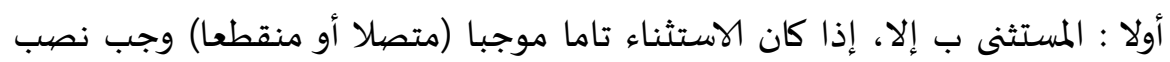
المستثنى. المثال : أتممت بناء المنزل إلا الأثاثَ. إذا كان الاستثناء تاما منفيا (متصهلا أو منقطعا) جاز نصب المستثنى وجاز اعرابه بدلا من المستثنى منـه. المثال: "ما أجاد الشعراءُ إلا شاعرا" بالنصب على الاستثناء، و"ما أجاد الشعراءُ إلا شـاعرّ" بالرفع على أنه بدل من المستثنى مناه،

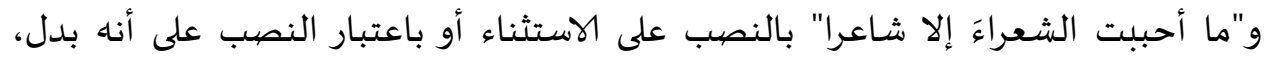

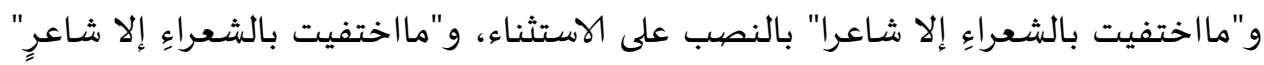
بالجر على البدلية. إذا كان المستثنى مفرغا، أعربنا المستثنى حسب العامل، فإن كان العامل يحتاج إلى اسم مرفوع رفعنا المستثنى، المثال: ما هو جم إلا الضعيف. فالضعيف نائب فاعل مرفوع, فإن كان العامل يحتاج إلى اسم منصيوب نصبينا المستثنى، المثال: لا نحترم إلا الشريفَ, فإن كان العامل يحتاج إلى اسم مجرور جررنا المستثنى، المثال: ما شهدت إلا بالحق. (كتاب الموسوعة النحوية ولصرفية الميسرة : ص :rV). إذا تكررت إلا كان للمستثنى أحواله المبينة في الجدول الآتي :

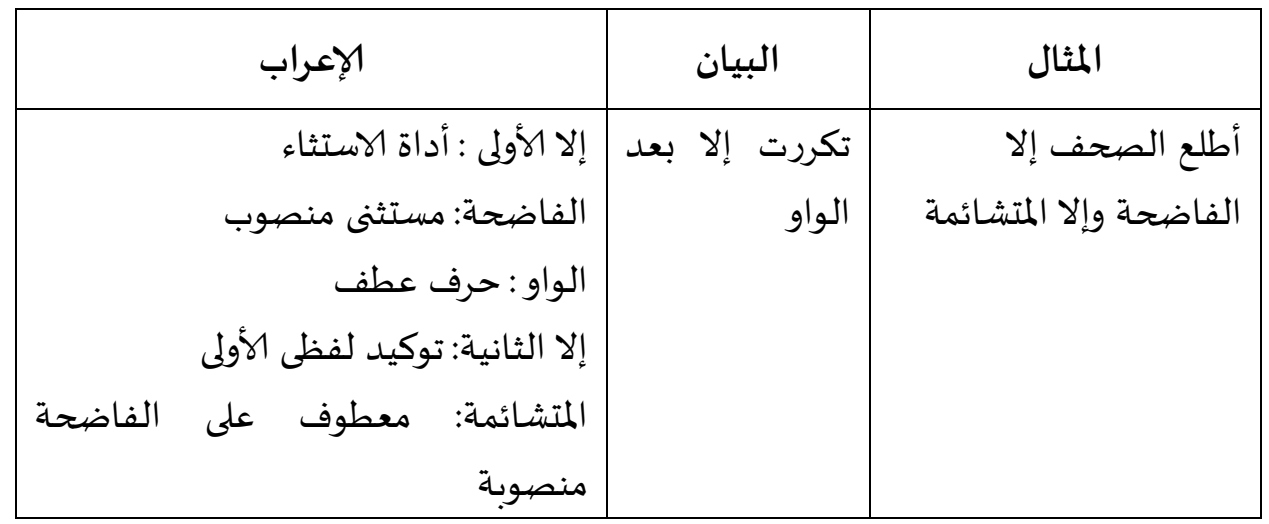




\begin{tabular}{|c|c|c|}
\hline الإلا : أداضحة: مستثنى منصيوب & تكررت إلا دون & أطلع الصحف إلاض \\
\hline الصحف الأولى: فاعل مرفوع & تكررت إلا & ما راجت إلا الصحف \\
\hline الادبية: صفة & والاستثناء مفرغ & الادبية إلا الصحف \\
\hline الصحف الثانية: مستثنى منصوب & & السيسية إلا الصحف \\
\hline السياسية: صفة & & 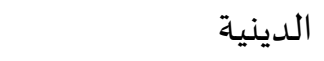 \\
\hline الصحف الثالثة: مستثنى منصوب & & \\
\hline
\end{tabular}

والمستثنى بغير إذا كانت أداة الاستثناء هي غير فالمستثنى بعدها مجرور بالإضيافة وتأخذ غير حكم المستثنى ب إلا في كل احواله . (كتاب الموسوعة النحوية ولصرفية الميسرة : ص : 1 ). أما المستثنى بسوى فحكماه هو حكم المستثنى بغير والفرق بين غير وسوى : أن غير تظهر عليها علامات الإعراب وأما سوى فعلامات الإعراب تقدر عليها. (كتاب الموسوعة النحوية

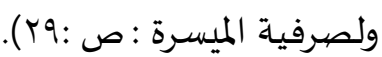

والمستثنى ليس منصوب على أنه خبر ليس واسمها ضمير مستتر جوازا تقديره هو ومثاله : اثمرت الاشجار ليس شجرة قديمة. وتستعمل ليس في الاستثناء التام المتصل (الموجب والمنفي) ولا تستعمل في الاستثناء التام المنقطع فلا تقل : اشترت الكتب وليس المكتب. (كتاب الموسوعة النحوية والصرفية الميسرة : ص :9 ب). وحكم المستثنى لا يكون هو حكم المستثنى ليس ولا تستعمل معها من ادوات النفي إلا أداة النفي لا ومثالها : اثمرت الاشجار لا يكون شجرة قديمة. (كتاب الموسوعة النحوية والصرفية الميسرة : ص :وب). المستثنى بعد "خلا - عدا - حاشـا" يجوز نسبه على أن هذه الادوات أفعال والمستثنى مفعول باه لفاعل مستتر وجوبا تقديره هو ويجوز جر المستثنى على أهنا احرف الجر. (كتاب

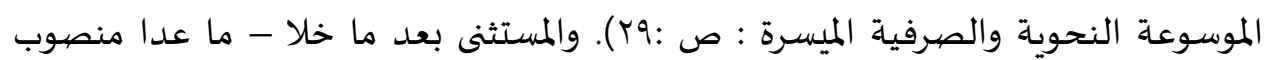
على أنه مفعول باه وهما فعلان ماضيان والفاعل ضمير مستتر وجوبا تقديره هو. ودخول ياء

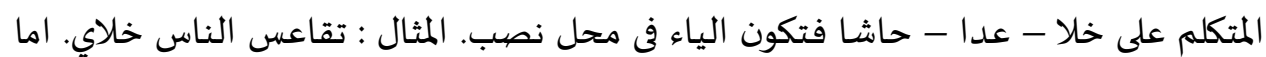
إن كانت مسبوقة ما فالياء فى محل نصب فقط. ويجوز دخول نون الوقاية مع ياء المتكلم (خملم فتقول: (خلاني - ما خلاني ) (عداني - ما عداني) (حاشاني). (كتاب الموسوعة النحوية والصرفية الميسرة : ص :وب). 
Ta'lim al-'Arabiyyah

البلاغة

البلاغة فى اللغة (الوصول والإنتهاء) يقال بلغ فلان مراده-إذا وصل إلياه، وبلغ الركب

المدينة - إذا انتهى إليها "تأدياة المعنى الجليل واضحا بعبارة صحيحة فصيحة" ومبلغ الشئ منتهاه. وتقع البلاغة في الإصطلاح: وصفا للكلام, والمتكلم فقط. ولا توصف الكلمة بالبلاغة لقصورها عن الوصول بالمتكلم إلى غرضها ولعدم السماع بذلك.(أحمد الهاشمى السيد المحرم, جواهر البلاغة، ص اسم).

البلاغة تتناول القواعد التي تحكم العمل الأدبي لإيضياح المعنى الواحد بعبارة واضحة وبصور مختلفة من تشبيه ومجازوكناية (علم البيان) ، ومدى مطابقة الكلام لمقتضى أحوال

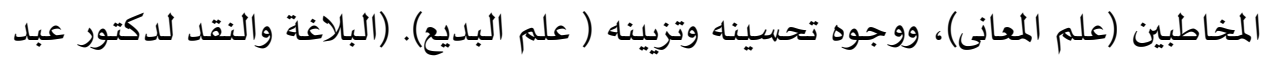

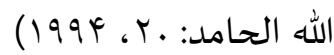

وجوه البلاغة

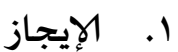

الإيجاز هو أن يعبر عن المعانى الكثيرة بألفاظ قليلة وافية بالمقصود مع الإفصاح وهو قسمان : إيجاز القصر وهو التعبير عن المعانى الكثيرة بألفاظ قليلة من غير حذف. وإيجاز الحذف وهو التعبير عن المعانى الكثيرة بألفاظ قليلة بحذف كلمة أو جملة أو أكثر من جملة

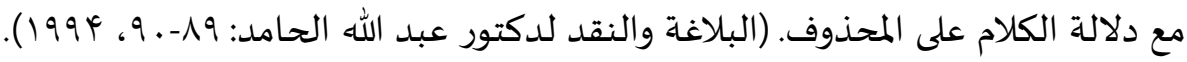
ومن بديع الإيجاز قوله تعالى: (قل هو الله أحد) إلى أخرها، فإنها نهاية التنزيه، وقد

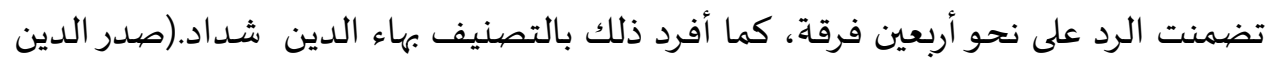
المدني، علي بن أحمد بن محمد معصوم الحسني الحسيني، المعروف بعلي خان بن ميرزا

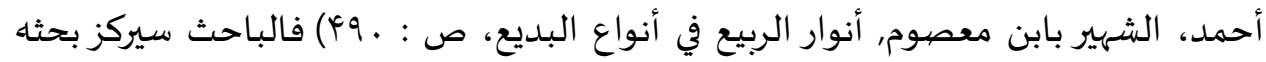
موضوعين عن الإيجاز ونوع واحد من الإطناب وهو ذكر الخاص بعد العام فقط ليس كلها وبدون المساوة بسبب لايتعلق مع موضوعاء الذي يتضمن فى سورةالعصر إلا الإيجاز لأن آياتها القصيرة بل معناها طويلة، ونوع الإطناب ذكر الخاص بعد العام فقط.

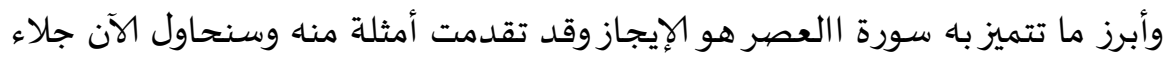
الأغراض الكامنة في إيجازها وحصر متنها وتقارب طرفيها، وسنحاول أن نبسط ذلك بسطا يوضّح المقصود ويدرك به الهدف. (إعراب القران وبيانه لمحيي الدين درويش: 9 الج الإطناب 
هو التعبير عن المعانى بألفظ تزيد عليها لفائدة. (البلاغة والنقد لدكتور عبد الله الحامد: 19(1994.9.

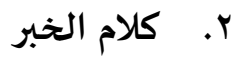

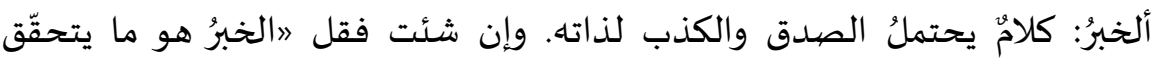

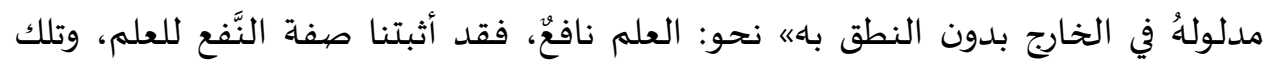

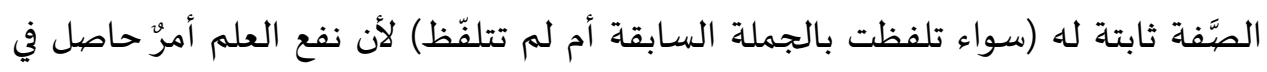

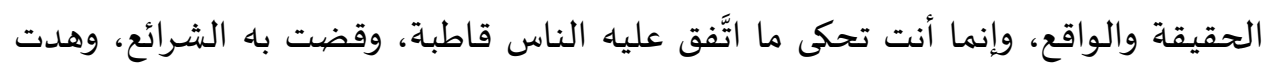
إليه العقولُ، بدون نظر إلى إثبات جديد.

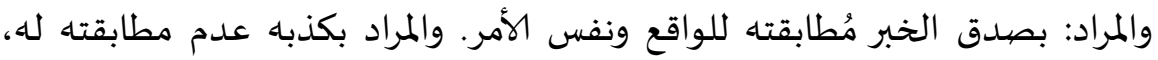

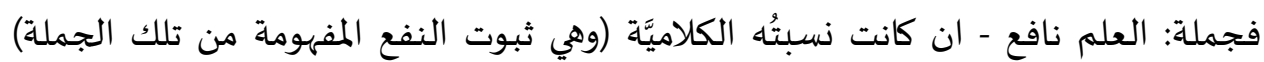

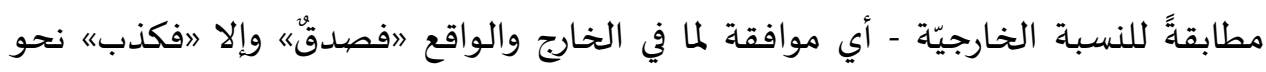

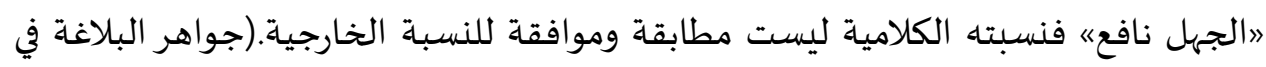

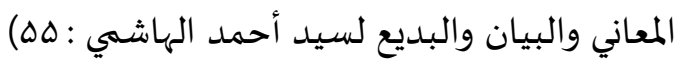
r. إملام الإنشاء هو كلام لا يحتمل صلدقا ولا كذبا لذاته او ما لا يحصل مضيمونه ولا يتحقق إلا الا

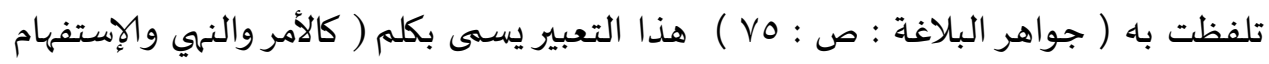

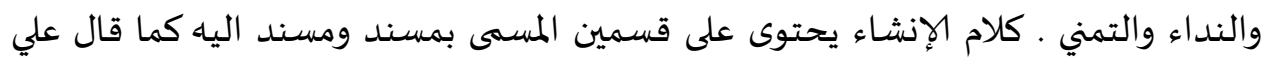

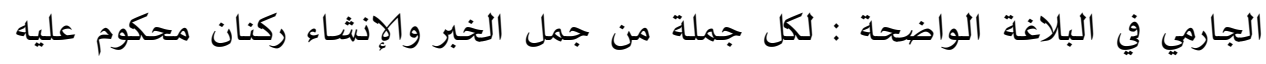

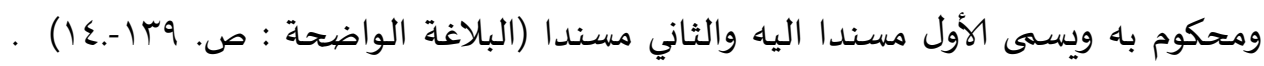

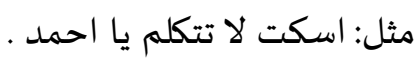
وينقسم كلام الإنشاء الى قسمين وهما الإنشاء الطلبي والإنشاء غير الطلبي . (1) إنشاء طلبي هو ما يستدعى مطلوبا غير حاصل وقت الطلب ويكون بالأمر والنهي

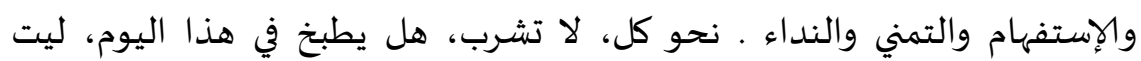

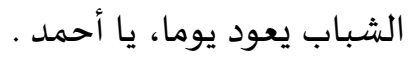

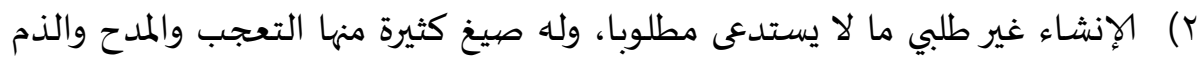
والقسم والرجاء . (هذا البيان الذي يؤخذ من توضيح البلاغة الواضحة). 
Ta'lim al-'Arabiyyah

$$
\text { ع. ذكر الخاص بعد العام }
$$

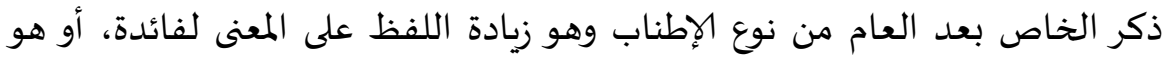

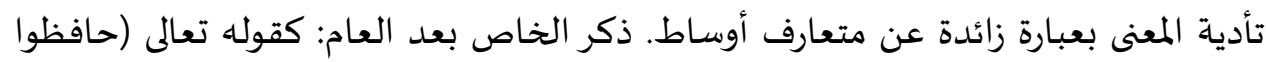

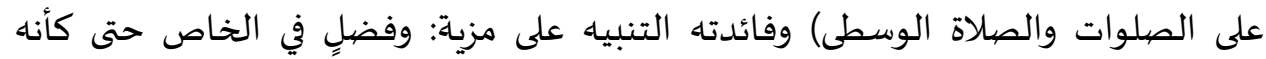

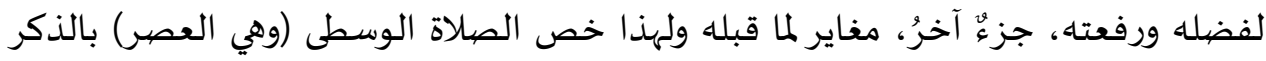

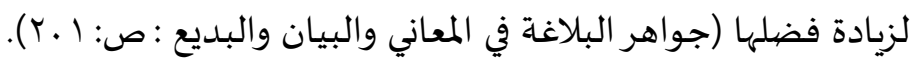

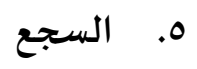

السجع: هو توافق الفاصلتين أو الفواصل في الحرف الاخير- والفاصلة في النثر كالقافية في الشعر- وموطن السجع النثر، وأحسنه ما تساوت فقراته، كقوله تعالى قُلْ هُوَ آلألَُّ

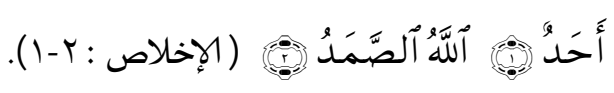

السجع ينقسم إلى ثلاثة أقسام، السجع المطرف وهو توافق بين لفظه وحروفه

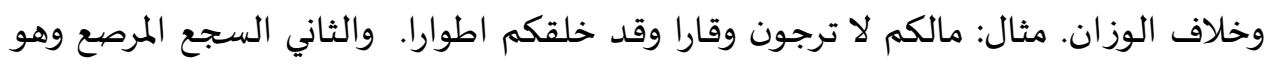

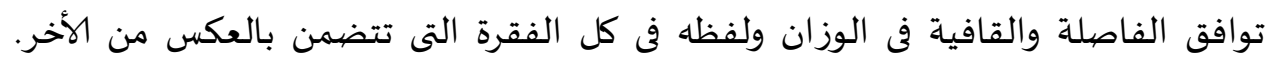

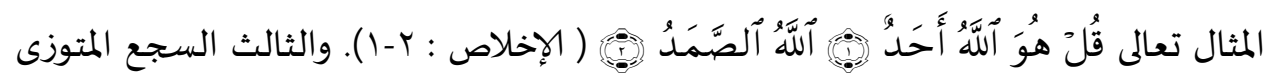

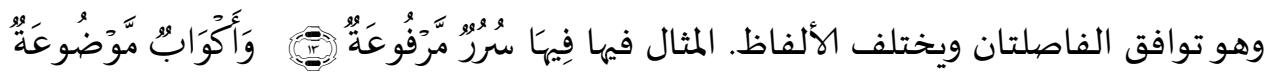

\begin{tabular}{|c|c|c|c|}
\hline البلاغية & آية & وجوه البلاغية & 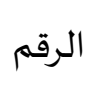 \\
\hline علم المعاني & 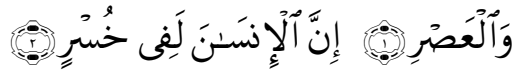 & الإيجاز & 1 \\
\hline علم المعاني & 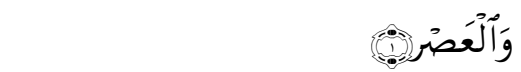 & الإنشاء الطلبى & r \\
\hline علم المعاني & جميع الآية & الخبر & r \\
\hline
\end{tabular}

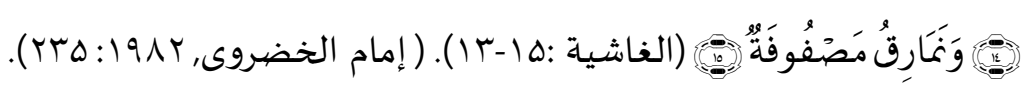

الإستقراء: أن وجوه البلاغة المضمونة في سورة العصر هي بالجدول كما يلى 


\begin{tabular}{|c|c|c|c|}
\hline علم المعاني & 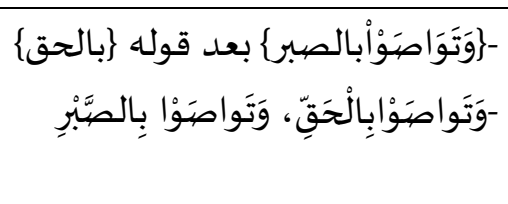 & - إلعناب:ذكر الخاص بعد & $\varepsilon$ \\
\hline 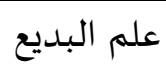 & 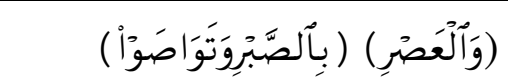 & السجع المطرف & 0 \\
\hline
\end{tabular}

\section{النتيجة}

من ناحية علم النحو كانت سورة العصر تتضمن من واو القسم وجواب القسم في الآية الثانية بعامل إنّ ولام الإبتداء ومستثنى إلا (أداة الإستثناء) والذين مستثنى من الإنسان

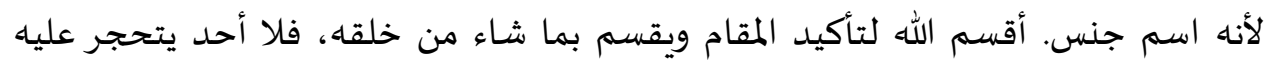

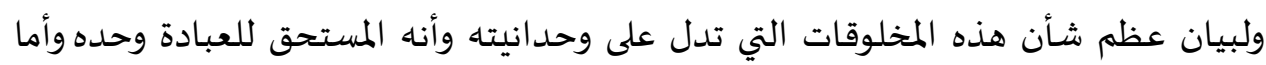

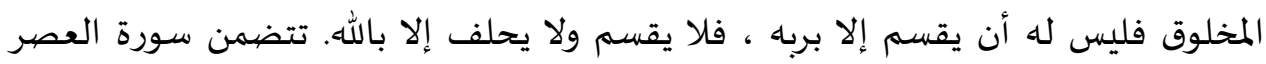

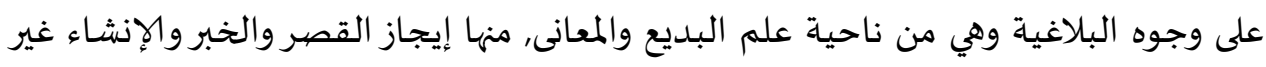

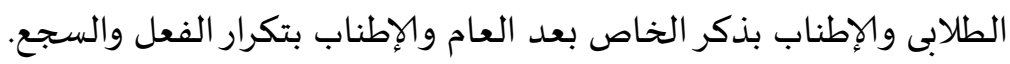

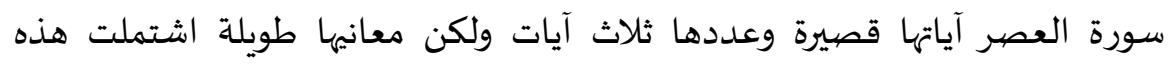

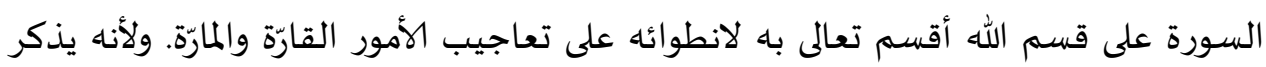

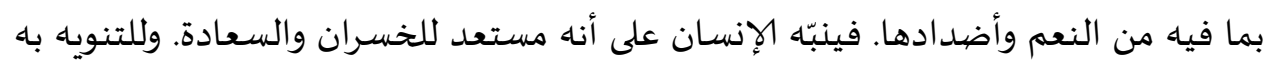

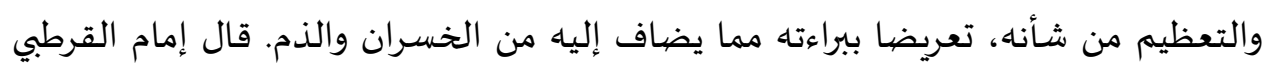

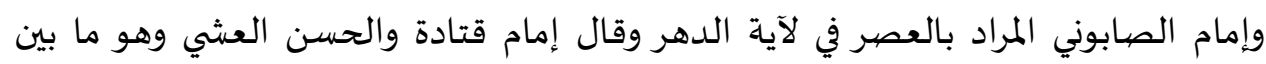

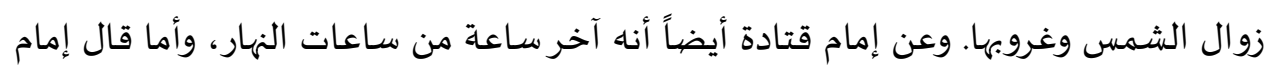

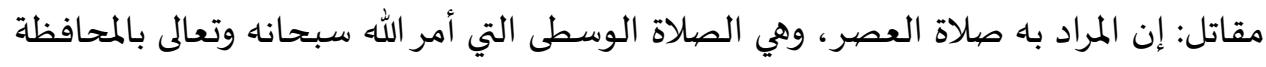

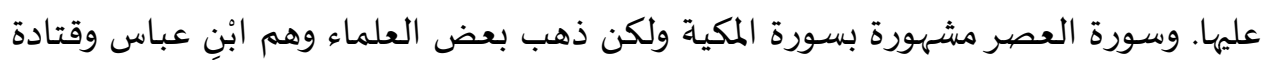
إسماعيل حقي بن مصطفى الإستانبولي بأنها المدنية ليست المكية.

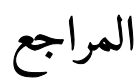
أبو عبد الله، ابن آجُرُّوم، محمد بن محمد بن داود الصنهاجي. 1991. متن الأجرومية، دار 
Ta’lim al-'Arabiyyah

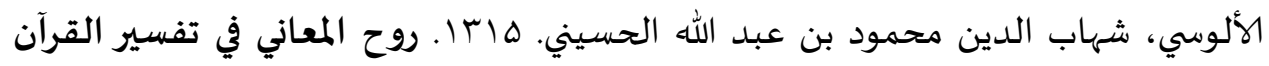

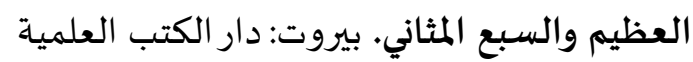

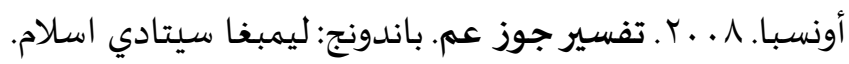
البخاري. 917 17. صحيح البخاري. دمشق، بيروت: دار القلم.

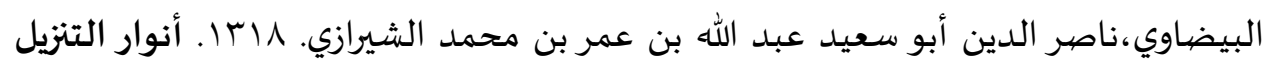
وأسرار التأويل=تفسير البيضاوي. بيروت: دار إحياء التيد بن التراث العربي.

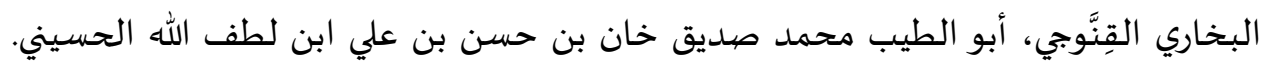

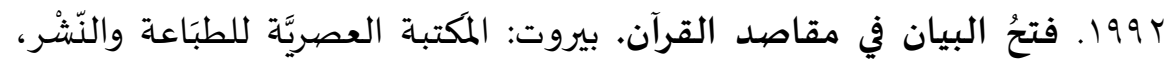
صَيدَا.

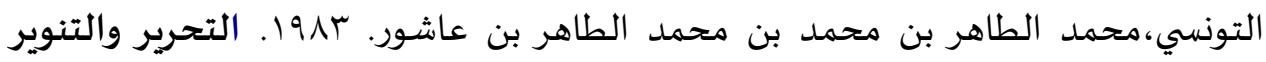

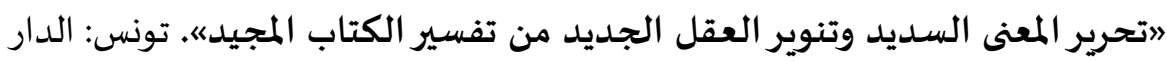
التونسية للنشر. الجهيلي. 1991. تفسير منير. بيروت: دار الفكر. الخطيب، عبد الكريم يونس. ـ9 ا ا. التفسير القرآني للقرآن. القاهرة: دار الفكر العربي. درويش،محيبي الدين بن أحمد مصطفى. هابـا. إعراب القرآن وبيانه. دمشقى: دار اليمامة. Ali Al-Jarim \& Musthafa Amin. 2000. Terjemahan Al-Balaghatul Waadhihah. Bandung: Sinar Baru Algesindo.

DJunaidi Fauzan, Mansur. 2012. Metodologi Penelitian Kualitatif. Yogyakarta: ArRuzz Media. 